\title{
DETERMINING THE OPTIMUM PROPORTION OF SHEA WASTE IN ANAEROBIC CO-FERMENTATION PROCESS
}

\author{
M.A. Ofosu ${ }^{1}$ and E.D. Aklaku ${ }^{2}$ \\ ${ }^{1}$ Department of Agric. Mechanization and Irrigation Technology, \\ University for Development Studies, P.O. Box TL1882, Tamale. \\ ${ }^{2}$ Department of Agricultural Engineering, KNUST, Kumasi.
}

\begin{abstract}
In search for an alternative source of energy, various feedstocks and wastes are being investigated to identify their potential in methane generation through anaerobic digestion. The addition of cattle manure to the predominant substrate is reported to have positive effect on the cofermentation process thereby improving the buffer capacity. The manure is also essential for the digestion in order to have a relatively stable process. The proportion of cattle manure in the mix substrate influences the stability of the anaerobic digestion process. In this study cofermentation treatments with varying proportions of shea waste and cattle manure were investigated. It was found out that only the treatment with $50 \%$ by volume of cattle manure showed process stability, producing biogas with high methane content.
\end{abstract}

Keywords: anaerobic digestion, co-fermentation, process stability, co-substrate, shea waste

\section{INTRODUCTION}

Interest has been growing in anaerobic digestion of organic wastes from surplus crop and crop residues especially from food and agroindustries for the generation of energy (Kaparaju and Rintala, 2005). One of the key constraints to development in developing countries is lack of or inadequate energy supplies. The process to achieve sustainability in energy is global, ongoing and never-ending in a world, where 1.6 billion people live without commercial energy; where one billion of the world's population of six billion use nearly $60 \%$ of the energy consumed and five billion, the other $40 \%$ (ICC, 2001). There is a close relationship between energy consumption and economic growth, especially in the initial phases of industrialization (Hohlfeld and Sasse, 1985), and it becomes more than obvious that the long-term satisfaction of basic human needs in developing countries will entail a considerable increase in per-capita energy consumption. Looking at the current major energy sources, none of them appears to offer security in terms of stable supply or environmental considerations. In the midst of abundant organic wastes and energy crops, there is the need to develop alternative sources of sustainable energy. Anaerobic digestion is brought about by a consortium of interdependent and symbiotic populations of heterotrophic microorganisms, which are capable of utilizing a diverse spectrum of substrates in the 


\section{Ofosu and Aklaku}

absence of oxygen for the synthesis of new cellular materials and production of various end -products (Ghaly, 1996). Anaerobic digestion has been demonstrated to be technically feasible for the wide range of feedstock based on moisture content, and it produces biogas with high methane content typically around $60 \%$ which can be manipulated upwards. A biogas plant can digest materials such as cowdung, crop waste, food processing effluent, weeds, leaves and non-edible starch as well as municipal and other wastes. Anaerobic conversion of crop biomass into methane is one way in which renewable raw materials may be used as an energy supply (Zauner and Kuntzel, 1986).

Biogas comprises principally the combustible methane $\left(\mathrm{CH}_{4}\right)$ and the incombustible carbon dioxide $\left(\mathrm{CO}_{2}\right)$. The quality of the biogas is determined by the composition of methane and carbon dioxide, and it is therefore a crucial factor in determining the viability of the biogas anaerobic digestion process. The anaerobic digestion process is a simple and a potential conversion system for wastes and biomass into valuable energy.

In anaerobic digestion, co-fermentation is the term used to describe the combined treatment of several wastes or biomass with complementary characteristics. This is one of the main advantages of the anaerobic technology. The co -fermentation or co-digestion of organic wastes involves the mixing of the various substrates in varying proportions. If all other factors are held constant, the specific methane yield $\left(\mathrm{m}^{3} / \mathrm{kg}\right.$ VS added or destroyed) and the percentage volatile solids destruction are functions of only the proportions of organic matter used (Misi and Forster, 2001).

There are numerous non-agricultural organic wastes that have been introduced to farm digesters as co-substrates. These additional feedstocks or co-substrates are derived mainly from agro- and food industries as well as from municipalities (biogenic wastes). In this paper the feedstock or the co-substrate referred to is the shea waste, the by-product from the extraction of shea butter from shea nuts by pressing. This by-product has not found any appreciable use up to this time. Shea nuts contain $40-55 \%$ fat (Head et al., 1995) and with the extraction by screw pressing about $13 \%$ of the fat is disposed of with the cake (Kyei 2005, Personal communication). Feedstocks containing fat (lipids) are known to be attractive for biogas production due to the fact that they are reduced organic materials and have high theoretical methane potential (Fernandez et al., 2005). However, anaerobic treatment of organic wastes with high lipid content presents problems, as it has been widely reported that high long-chain fatty acids (LCFA) concentrations can destabilize anaerobic digesters due to inhibition of methanogenic bacteria by possible damage to cellular membrane (Hanaki et al., 1981).

Anaerobic digestion of shea wastes is therefore expected to present problems, and to establish suitable fermentation technologies basic information is required on biological parameters of the biogas production. The objective of the paper is to investigate the share proportion in co-fermentation of shea waste for optimum biogas/methane production under continuousflow system and to determine the optimal operational conditions at the steady state.

\section{MATERIALS AND METHODS}

The study was carried out at the Nyankpala Campus of the University for Development Studies, Tamale and the experiment was conducted in the Biogas Laboratory of the Faculty of Agriculture. The study was carried out with six 74-litre horizontal, half-technical fermentation plants. Each fermentation unit comprised a digester (fermenter) with a manual stirrer, a pressure compensation bottle, a gasholder with a counterweight and an attached scale. The components of the fermentation unit with other accessories are shown in a schematic diagram (Fig.1).

\section{Shea waste}

Shea cake is the by-product in the production of shea butter, and it is the main feedstock in this investigation. In the course of the laboratory investigation, the cake was periodically col- 
lected from Shebu Industries at Savelugu, a distance of $22 \mathrm{~km}$ northward from Tamale. Shebu Industries processes about 9300 metric tonnes of shea-nuts per year (Kyei 2005, Personal communication). The cake collected for the study was stored in polypropylene sacks at ambient conditions in the laboratory.

\section{Cattle manure}

Cattle manure (cow-dung) is the basic substrate in anaerobic digestion. Cow-dung was cultured to produce inoculum for the biogas process. For the preparation of the inoculum and subsequent needs of cattle manure for the study, fresh cowdung was collected daily from a kraal in a neighbourhood village, Kpachi, which is about $2 \mathrm{~km}$ from the Nyankpala campus of the University.

\section{Preparation of input substrates}

The initial feeding of the digester was done with the basic substrate cow-dung mixed with water in a ratio of $1: 1$ by weight, to produce an inoculum for the experiment. Each digester was filled with this cow-dung slurry and the substrate was allowed to stand for two weeks for the production of the inoculum. In order to acquire fluid properties and to enable it to be applied as feedstock in a digester, the cake was always soaked in a measured quantity of water

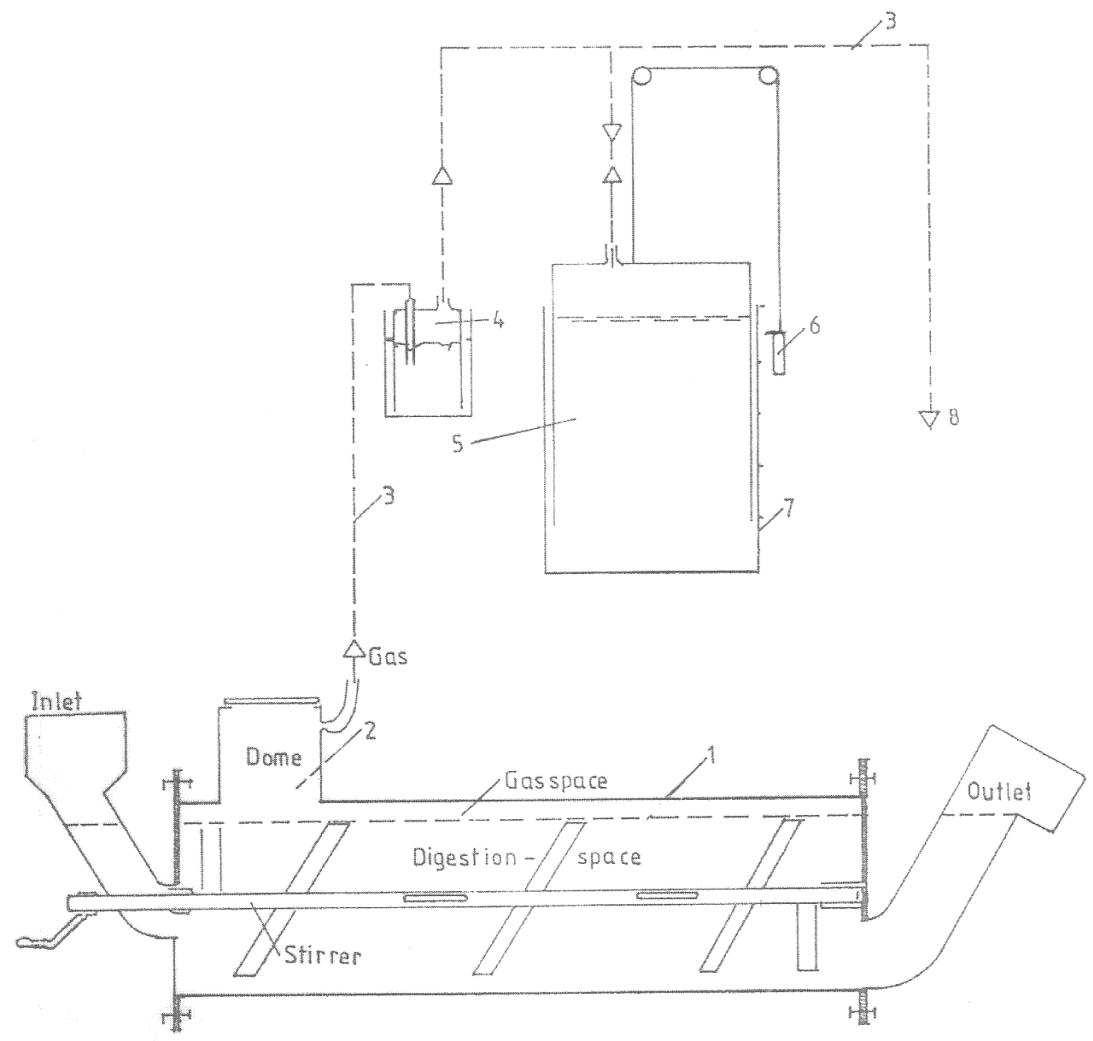
1. Digester
5. Gas holder
2. Gas Exit
6. Compensation weight
3. Plastic hose
7. Scale
4. Pressure compensation
8. Central gas analysis

Fig.1: Schematic diagram of the fermentation unit 


\section{Ofosu and Aklaku}

for about 30 minutes to obtain an appropriate substrate concentration for digestion. The initial shea-waste to water ratio used was $1: 7$ by weight, giving an organic dry matter concentration (odm) of shea of approximately $11 \%$. Further sample dilution was undertaken to obtain the expected input substrate concentrations of odm $7 \%$.

\section{Experimental Treatments}

The co-fermentation or co-digestion of organic wastes involves the mixing of the various substrates in varying proportions. To determine the optimum shea:cow-dung ratio for the anaerobic digestion and to ensure process stability, three co-fermentation treatments were chosen. The chosen treatments were the shea-waste to cowdung ratio (by volume) of 50:50, 75:25 and 90:10. Organic dry matter concentration of $7 \%$ for all treatment substrates and the hydraulic retention time (HRT) of 30 days were chosen to ensure high digester specific biogas production for the anaerobic digestion of shea waste for energy production. Each treatment was duplicated. A continuous-flow fermentation process was used. The daily flow-rate (feeding) volume is the reactor working volume divided by the HRT (30 days).

\section{Daily Operation}

Digester feeding, gas and substrate parameter readings were carried out on daily basis in the morning between 9.30am and 10.30am. Input substrates were always prepared before readings were taken so that the digesters could be fed immediately after the readings. Weight of fresh substrate to feed the digester was measured daily using Soehnle weighing scale to determine the organic loading rate.

The contents of the digesters were stirred before and after feeding to ensure uniformity and consistency in the effluent from the digester as well as an even distribution of bacteria within the substrate. Ten revolutions of stirring were undertaken at any of these times.

The ambient temperature of the laboratory was continuously recorded using Casella Standard thermo-hygrograph, which was placed in the room. Graph sheets for recording of room temperature and relative humidity were changed weekly.

\section{Determination of Biogas Parameters}

The biogas yield was determined daily. The volume of the biogas produced was determined by the position of the pointer on the counterweight on the calibrated scale attached to the gasholder.

Analysis of the biogas to determine its quality (composition), namely methane, carbon dioxide and hydrogen sulphide, was carried out using gas analyser Sewerin SR2 - DO. In order to reduce the amount of water vapour exposure on the equipment and to protect the equipment against excessive corrosion, a portion of the pipe (about $2 \mathrm{~cm}$ long) through which the biogas was directed to the equipment for analysis was filled with anhydrous calcium chloride $\left(\mathrm{CaCl}_{2}\right)$ powder. The analysis to determine the biogas composition was carried out daily by connecting the probe from the gas analyser to the exit pipe of the gasholder.

\section{Substrate parameters}

The $\mathrm{pH}$ values for the input and outflow substrates were measured daily using a digital $\mathrm{pH}-$ meter WTW $\mathrm{pH} 323 \mathrm{~A}$ through $\mathrm{pH}$ electrode Sentix 41 (the pH-meter also has an integrated temperature sensor). During the measurements, the $\mathrm{pH}$ electrode was kept in the substrate until the reading was stabilized.

The temperature of the digester content was measured daily with a digital thermometer Checktemp-01. The thermometer consists of a $1 \mathrm{~m}$ cable with a probe. To measure the temperature of the digester content about $8 \mathrm{~cm}$ of the probe was inserted into the substrate until the reading was stable.

The total solids and organic dry matter contents of the input substrate were also determined daily, whilst those of the outflow substrate were determined at weekly interval. To determine the total solids (dry weight), a sample of the substrate up to $35 \mathrm{~g}$ was placed in a Wagtech ventilated oven at temperature of $106^{\circ} \mathrm{C}$ for 24 
hours. Top loading electronic balance Mettler PM 480 Delta Range was used in the weight measurements. To determine the organic dry matter (volatile solids) of the substrate, the dry matter removed from the ventilated oven afterwards was placed in a Gallenkamp mufflefurnace at a temperature of $530^{\circ} \mathrm{C}$ for 4 hours. The corresponding loss in weight after burning in the furnace was thus the organic dry matter (odm) content or the volatile solids (VS) of the sample.

\section{RESULTS AND DISCUSSION}

Methane content

Biogas quality determined by the percentage methane content is vital in anaerobic digestion process. Figure 2 shows the methane content of the co-fermentation trials at the operating (ambient) temperatures and HRT of 30 days during the digestion periods. Comparing the methane content of the biogas from the three treatments on Day 17 showed shea-waste to cow-dung ratio of 50:50 $(50+50)$ having $60 \%$; shea-waste to cow-dung ratio of $75: 25(75+25)$ yielded $50 \%$; and shea-waste to cow-dung ratio of 90:10 $(90+10)$ with $42 \%$. Digester feeding for treatment $90+10$ was discontinued then, as it was evident that the methane content from this substrate was continuously declining. Treatments producing biogas with methane content below $50 \%$ by volume of biogas were terminated because for energy generation biogas with methane content considerably below $50 \%$ is incombustible (Sasse, 1988). On Day 25 the production trend of the methane content of the biogas of the remaining two treatments $50+50$ and $75+25$ were observed with the former achieving $64 \%$ and the latter with values declining to $44 \%$. The operation of treatment $75+25$ was also discontinued leaving only the treatment $50+50$ to continue. To be convinced that the anaerobic digestion of the substrate was stable, the methane content was observed up to the $33^{\text {rd }}$ day. For an experiment operating on 30 days HRT it was assumed that one digester feed volume turnover would be achieved after 30 days of feeding.

Treatment with shea-waste to cow-dung ratio $50: 50(50+50)$ showed amongst the others as the feasible anaerobic digestion option achieving a mean methane content of $60.9 \%$ for the entire period of the experimentation. The trend of fall and rise in methane content levels (Fig. 2 ) in co-fermentation of organic wastes with

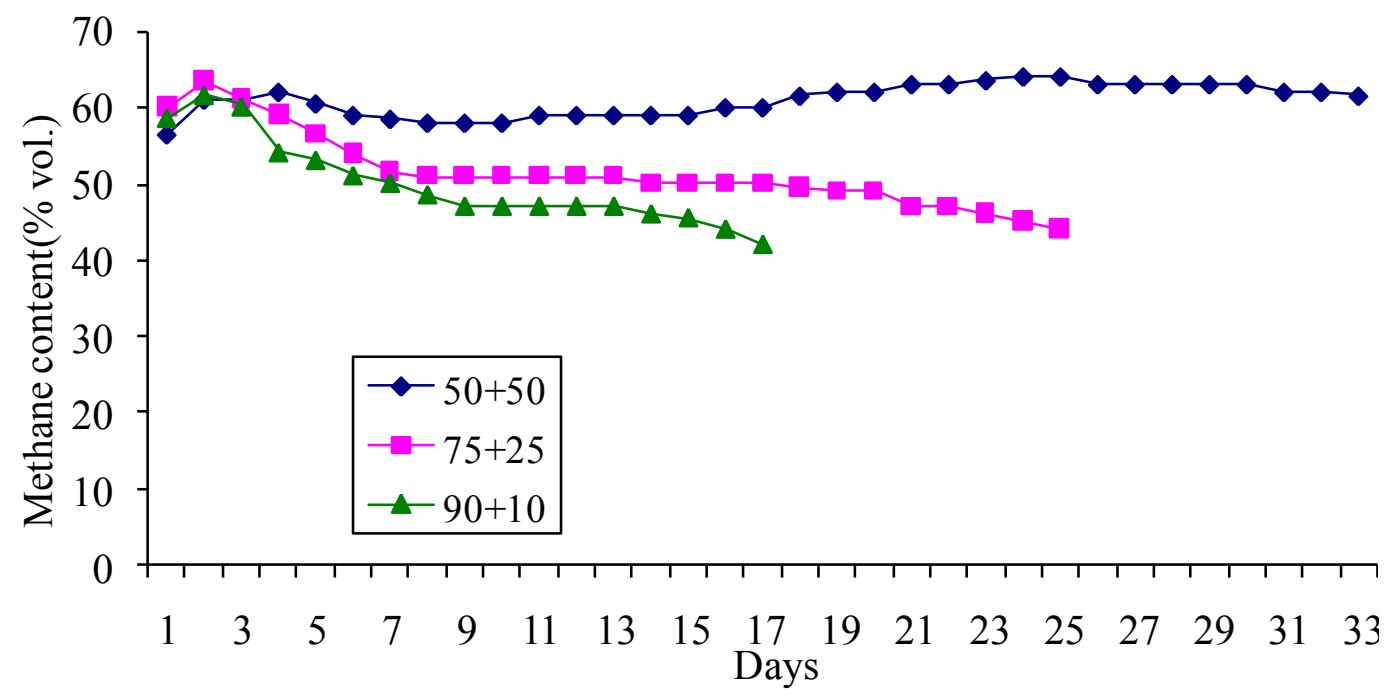

Fig. 2: Methane content in co-fermentation at different proportions 


\section{Ofosu and Aklaku}

cattle manure however, appears to be peculiar in anaerobic digestion of fatty substrates as evident in the work of Amon et al. (2002).

\section{Daily methane production rate}

Viability of anaerobic digestion process is influenced by the biogas/methane production rate, and methane production generally reflects the performance of the process. Considering the first 17 days of the fermentation process, as methane production rate from substrate with $50 \%$ shea waste was increasing towards a steady phase, the production rates from substrates $75+25$ and $90+10$ were declining, with that from $90+10$ declining at a faster rate (Fig.3). Mean daily methane production (litres/ day) for day 17 for the substrates $50+50,75+25$ and $90+10$ were $31.31,13.25$ and 2.06 respectively. Due to the declining methane production rate from the mix $90+10$, the digester feeding for the treatment was discontinued on the $17^{\text {th }}$ day, whilst feeding for treatments $75+25$ and $50+50$ continued. On the $25^{\text {th }}$ day when methane production from $50+50$ had reached a steady state with a value of 33.41 litres, production from $75+25$ had declined to 4.36 litres. Experiment $75+25$ was thus terminated on the $25^{\text {th }}$ day. The process stability of $50+50$ was further observed and confirmed by extending the fermentation to the $33^{\text {rd }}$ day.

\section{Specific methane yields}

Figure 4 shows the methane yield (litre $\mathrm{CH}_{4} / \mathrm{g}$ odm) achieved from the different proportion of co-digestate over the fermentation periods. The substrate specific methane yield for the various treatments followed the same trend as the methane production rates.

Average specific biogas/methane yields after 17 days; 25 days and 33 days periods of anaerobic fermentation for the three blends are shown in Table 1. Variations in digester temperature readings due to digester location in the laboratory were minimal and did not influence the results. Comparison of the three treatments at the end of 17 days showed the mix 50:50 having the highest outputs, whilst the mix 90:10 achieved the least.

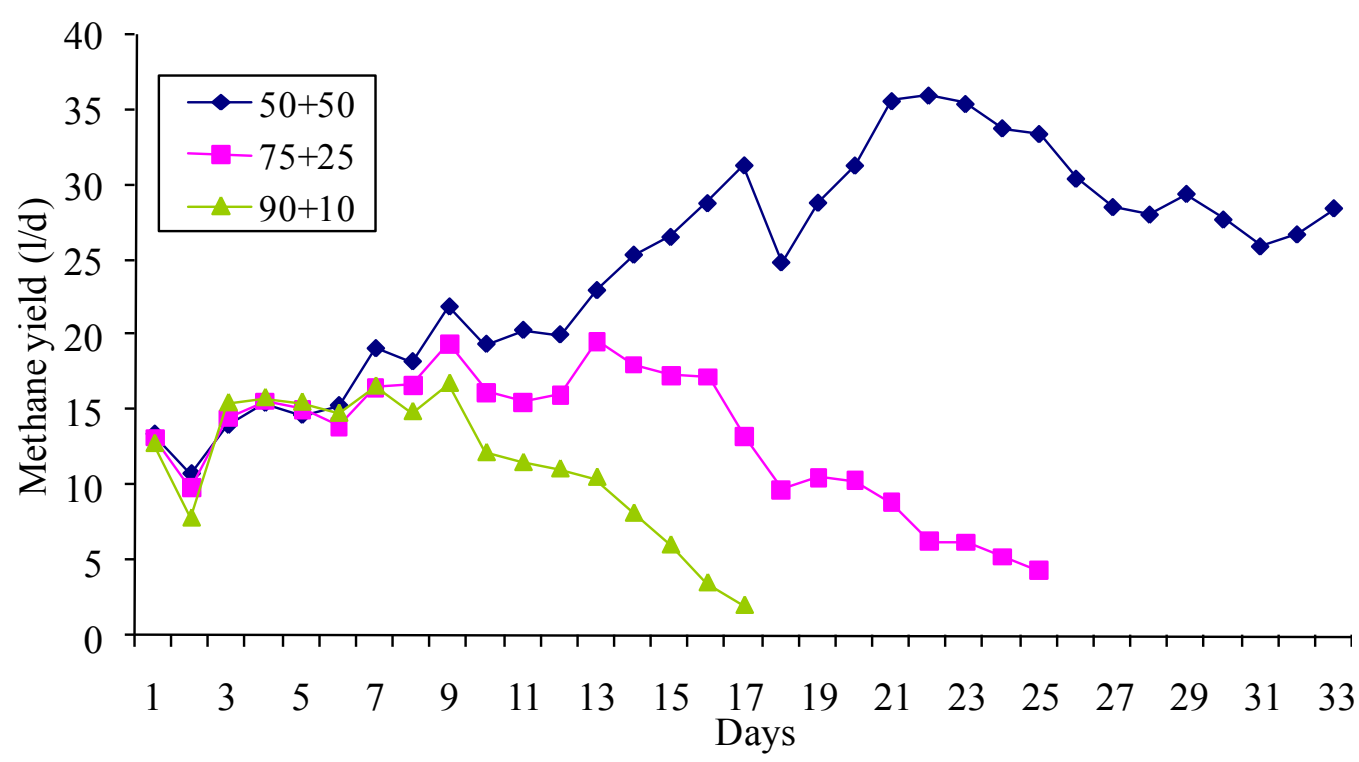

Fig. 3: Daily methane production in co-fermentation at different proportions 
After terminating treatment 90:10, comparison of the treatments $50: 50$ and $75: 25$ on the $25^{\text {th }}$ day showed that whilst the mix 50:50 had an increase over the 17 days period, the output from mix 75:25 showed a decrease, an indication of process instability with the substrate $75: 25$. The results from substrate $50: 50$ for the 33 days fermentation period however did not change significantly from the 25 days, confirming the digestion stability of the substrate.
pH-values

The $\mathrm{pH}$-value is central in the determination of the process stability and efficient biogas production. Anaerobic digestion process can be inhibited at low $\mathrm{pH}$ values (Callaghan et al., 2002). Ghaly and Ben-Hassan (1989), Person and Bartlett (1978) and Hashimoto et al. (1979) stated that methane production proceeds quite well as long as the $\mathrm{pH}$ is maintained between 6.6 and 7.6 with an optimum range between 7.0

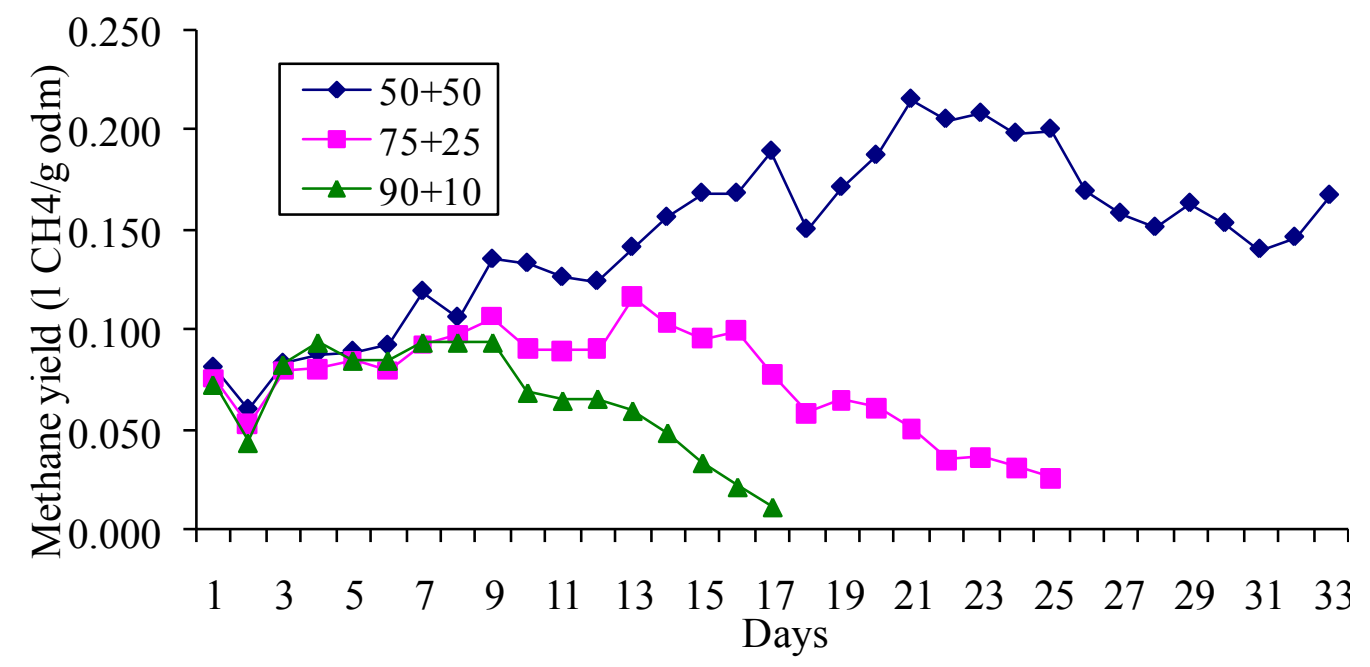

Fig. 4: Specific methane yield from three treatments

Table 1: Average reactor and substrate specific biogas/methane yield $\left(G_{R}, M_{R} ; G_{o d m}, M_{o d m}\right)$ (mean values from 2 replications over fermentation period of 17 to 33 days)

\begin{tabular}{|c|c|c|c|c|c|c|c|}
\hline $\begin{array}{c}\text { Mix } \\
\text { ratio } \\
\text { SH:CD } \\
\quad \%\end{array}$ & $\begin{array}{c}\text { Mean } \\
\text { Temp. } \\
{ }^{\mathbf{T}} \\
{ }^{0} \mathrm{C}\end{array}$ & $\begin{array}{l}\text { Organic } \\
\text { loading rate, } \\
\mathbf{L}_{\mathrm{D}} \\
(\mathrm{g} \mathrm{odm} / \mathrm{l} * \mathrm{~d})\end{array}$ & $\begin{array}{c}\text { Reactor sp. } \\
\text { biogas yield, } \\
\mathbf{X} \\
\mathbf{G}_{\mathrm{R}} \\
\left(1 / 1^{*} \mathrm{~d}\right)\end{array}$ & $\begin{array}{c}\text { Reactor sp. } \\
\text { methane yield, } \\
X \\
M_{R} \\
\left(1 / I^{*} d\right)\end{array}$ & $\begin{array}{l}\text { Substrate sp. } \\
\text { biogas yield, } \\
\text { X } \\
\text { G }_{\text {odm }} \\
\text { (l/g odm) }\end{array}$ & $\begin{array}{c}\text { Substrate sp. } \\
\text { methane } \\
\text { yield, } \\
\text { X } \\
\mathbf{M}_{\text {odm }} \\
\text { (l/g odm) }\end{array}$ & Days \\
\hline $50: 50$ & $28.4 \pm 1.1$ & $2.27 \pm 0.12$ & $0.55 \pm 0.14$ & $0.34 \pm 0.10$ & $0.24 \pm 0.06$ & $0.15 \pm 0.04$ & 33 \\
\hline $50: 50$ & $28.2 \pm 1.2$ & $2.25 \pm 0.09$ & $0.53 \pm 0.16$ & $0.32 \pm 0.11$ & $0.24 \pm 0.07$ & $0.15 \pm 0.05$ & 25 \\
\hline $75: 25$ & $28.0 \pm 1.3$ & $2.36 \pm 0.09$ & $0.35 \pm 0.11$ & $0.18 \pm 0.06$ & $0.15 \pm 0.05$ & $0.08 \pm 0.03$ & 25 \\
\hline $50: 50$ & $27.9 \pm 1.2$ & $2.25 \pm 0.09$ & $0.45 \pm 0.13$ & $0.27 \pm 0.07$ & $0.21 \pm 0.06$ & $0.12 \pm 0.03$ & 17 \\
\hline $75: 25$ & $27.8 \pm 1.2$ & $2.36 \pm 0.09$ & $0.41 \pm 0.08$ & $0.21 \pm 0.03$ & $0.17 \pm 0.03$ & $0.09 \pm 0.02$ & 17 \\
\hline $90: 10$ & $27.8 \pm 1.2$ & $2.35 \pm 0.10$ & $0.31 \pm 0.12$ & $0.16 \pm 0.06$ & $0.13 \pm 0.05$ & $0.07 \pm 0.03$ & 17 \\
\hline
\end{tabular}

SH: shea waste, CD:cow-dung. Note: values are expressed as mean \pm standard deviation. 


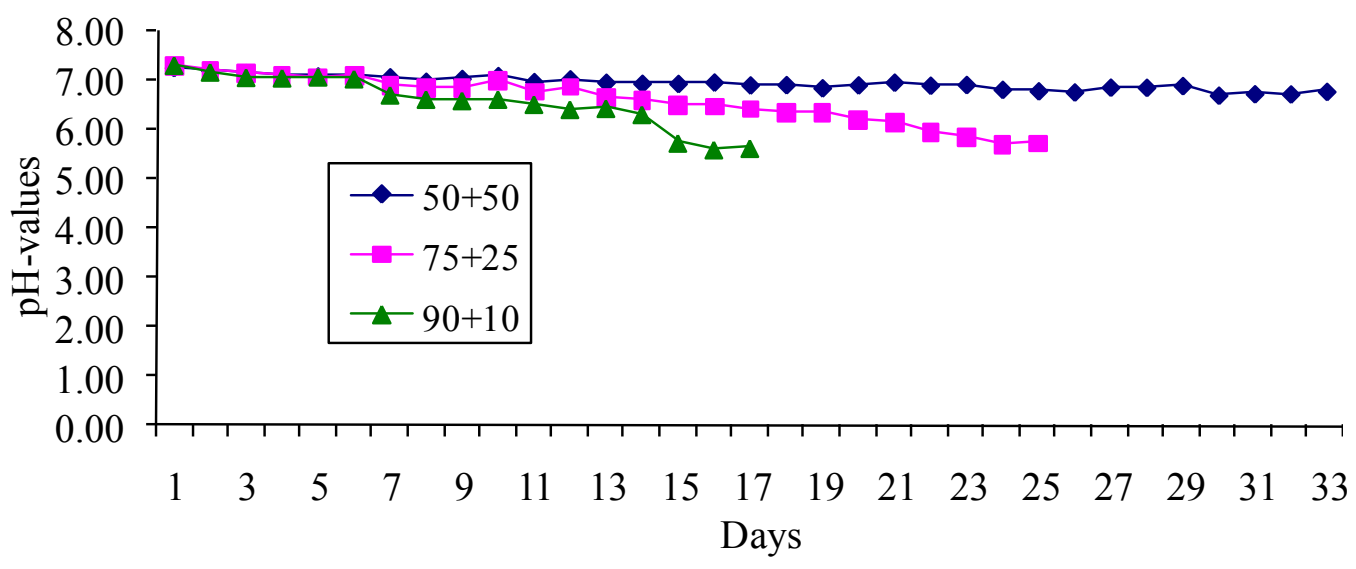

Fig. 5: pH-values of the different treatments

and 7.2. The experiments started with the initial $\mathrm{pH}$ in the reactors ( $\mathrm{pH}$ of inoculum) at almost the same value (approx. 7.3) for all treatments as shown in Fig. 5. Differences in $\mathrm{pH}$ of input substrates however influenced the performance and process stability of the treatments.

The mean $\mathrm{pH}$ values of the input substrates for the blends $50+50,75+25$ and $90+10$ were respectively $6.68,6.37$ and 6.09 . After the startup phase of fermentation a declining trend in the $\mathrm{pH}$ of all the treatments was observed. After 17 days of fermentation, the $\mathrm{pH}$ of substrate with $10 \%$ cow-dung addition $(90+10)$ had dropped to 5.6; substrate with $25 \%$ cow-dung addition $(75+25)$ had fallen to 6.43 , whilst the substrate $50+50$ after the 17 days was 6.91 (Fig.5). Bacteria require suitable conditions of $\mathrm{pH}$ and temperature to grow optimally and the bacteria concerned in the reactions in anaerobic digesters vary in optimum $\mathrm{pH}$ for growth (Hobson and Wheatley, 1993). If the $\mathrm{pH}$ of the content of a digester drops it indicates failure of the buffering mechanism and hence too much of acid is being produced (Fulford, 1998). The methanogenic bacteria are the most $\mathrm{pH}$ sensitive. If the $\mathrm{pH}$ decreases below 6 , an inhibition of the methane-forming bacteria can be observed as the volatile acids accumulate in the digester (Burton and Turner, 2003). Apparently, the low input-pH of substrate $90+10$ con- sequentially influenced negatively on its biogas production rate and the treatment had to be terminated on the $17^{\text {th }}$ day. Further observation on the other two treatments showed that by the $25^{\text {th }}$ day the $\mathrm{pH}$ of $75+25$ had also declined to 5.73 , the effect that was evident in the biogas production rate, whilst the $\mathrm{pH}$ of $50+50$ was 6.79 with gas production from the substrate reaching a steady state. At the end of the 33 days fermentation period, the $\mathrm{pH}$ of $50+50$ was 6.78 with biogas production still in the steady state.

Considering the input-pH of the three substrates it became obvious that the higher the cow-dung addition the more optimal the $\mathrm{pH}$ value of the mix substrate, and the closer the $\mathrm{pH}$ value to the optimal the more stable the anaerobic digestion process. The addition of cattle manure to improve the buffer capacity is reported as a positive effect in the co-fermentation process (Mshandete et al., 2004). The $\mathrm{pH}$-values for digester substrates $75+25$ and $90+10$ during the first 17 days fermentation period showed declining trends to levels, which were indicative of process instability. The treatment with $50 \%$ cattle slurry in the mix substrate showed greater process stability and the $\mathrm{pH}$ value of that blend was closer to the optimal range of 6.8-7.2 (Abdel-Hadi, 2003). 
Co-fermentation of shea waste with cow-dung was shown to be a viable option in anaerobic digestion, however the proportion of cattle manure in the mix was a determining factor in the stability of the process. Steffen et al. (1999) reported that up to $80 \%$ co-substrate addition could be applied in some cases to enhance the performance of agricultural digesters. However this investigation showed that process stability was reached with co-substrate (shea waste) addition of only $50 \%$. In the anaerobic digestion of cheese whey and dairy manure, Ghaly (1996) observed that controlling the $\mathrm{pH}$ of the methanogenic stage in the outlet chamber increased the biogas production rate from cheese whey by a factor of 2.7-3.0. Without controlling the $\mathrm{pH}$ of the cheese whey the biogas production rate of the dairy manure was observed to be higher than that of the cheese whey at all hydraulic retention times and temperature. This was attributed to low $\mathrm{pH}(5.7-6.0)$ of cheese whey as compared to that of dairy manure (Ghaly, 1996). Wildenauer and Winter (1985) also reported that in conventional mixed reactors at $\mathrm{pH}$ values below 6.6 , acute toxicity occurs and washout of the bacteria would occur at a pH below 5.3.

It was evident from the experiment that substrate $50+50$ with $\mathrm{pH}$ closer to the optimal provided optimum conditions for bacteria growth leading to a stable anaerobic digestion process. The higher the shea waste addition, beyond $50 \%$, the more unstable the anaerobic digestion process. This instability is attributed to high volatile fatty acids (VFA) in the shea waste leading to low $\mathrm{pH}$ of the substrate, as one of the criteria for judging digester stability is the VFA:alkalinity ratio (Callaghan et al., 2002). The VFA concentration via chemical equilibrium influences the $\mathrm{pH}$ in the waste and, for a specific waste composition, the VFA concentration and $\mathrm{pH}$ can be related to each other (Veeken et al., 2000). Increasing the cattle manure proportion in the shea substrate reduced the inhibition of the methanogens, whilst improving the substrate $\mathrm{pH}$ to the optimal value conducive to achieve anaerobic process stability and increase the buffer capacity of the sub- strate as well. Anaerobic digestion of the substrates shea-waste to cow-dung ratio 90:10 and 75:25 were not considered stable, generally due to low values obtained in methane content in biogas, daily methane production, specific methane yield and $\mathrm{pH}$ during the respective fermentation periods.

\section{CONCLUSION}

Co-fermentation of shea waste with cattle manure was found to be a feasible anaerobic digestion option in the generation of methane. However in the trials only the substrate with $50 \%$ cattle manure addition (shea-waste to cow -dung ratio (by volume) of 50:50) showed process stability, producing biogas with high percentage methane content. The investigation showed that in co-fermentation process the greater the cattle manure addition the higher the process stability, and the closer the $\mathrm{pH}$ value of digester substrate to the optimum. As the amount of shea waste in the substrate increased, $\mathrm{pH}$ decreased affecting the anaerobic digestion process.

\section{ACKNOWLEDGEMENT}

This study was conducted with support from the World Bank and Agricultural Sub-Sector Improvement Project (AgSSIP) of the Council for Scientific and Industrial Research (CSIR).

\section{REFERENCES}

Abdel-Hadi, M. (2003). Methane generation out of food waste and beta beets. PhD Thesis, University of Hohenheim, MEG Publications, No. 403, Stuttgart, pp. 56-57.

Amon, Th., Boxberger, J., Lindworsky, J. and Scheibler, M. (2002). Cofermentation of organic wastes and agricultural manures. Biomass for Energy and Industry: $160-$ 162.

Burton, C.H. and Turner, C. (2003). Manure Management: Treatment strategies for sustainable agriculture, Silsoe Research Institute 2003, Bedford, pp. 276-292.

Callaghan, F.J., Wase, D.A.J., Thayanithy, K. and Forster, C.F. (2002). Continuous co- 


\section{Ofosu and Aklaku}

digestion of cattle slurry with fruit and vegetable wastes and chicken manure. Biomass and Bioenergy, 27: 71-77.

Fernandez, A., Sanchez, A. and Font, X. (2005). Anaerobic co-digestion of a simulated organic fraction of municipal solid wastes and fats of animal and vegetable origin. Biochem. Eng. J., 26: 2228.

Fulford, D. (1998). Running a Biogas Programme: A Handbook. Intermediate Technology Publications, London, pp. 30- 34.

Ghaly, A.E. (1996). A Comparative Study of Anaerobic Digestion of Acid Cheese Whey and Dairy Manure in a Two-stage Reactor. Bioresource Technology, 58: 61-72.

Ghaly, A.E. and Ben-Hassan,R.M. (1989). Continuous production of biogas from dairy manure using and innovative no-mix reactor. Appl. Biochem. Biotechnol. J., 20/21: 541-559.

Hanaki, K., Matsuo, T. and Nagase, M. (1981). Mechanism of inhibition caused by longchain fatty acids in anaerobic digestion process. Biotechnol. Bioengg., 23: 15911610.

Hashimoto, A.G., Chen, Y.R. and Prior, R.L. (1979). Methane and protein products from animal feedlot waste. J. Soil Water Conservation, 34(1): $16-19$.

Head, S.W., Swetman, A.A., Hammonds, T.W., Gordon, A., Southwell, K.H. and Harris, R.V. (1995). Small Scale Vegetable Oil Extraction. NRI, Chatham, pp. 60-61.

Hobson, P.N. and Wheatley A.D. (1993). Anaerobic Digestion: Modern Theory and Practice. Elsevier Science Publishers Ltd., London, pp. 7-21.

Hohlfeld, J. and Sasse, L. (1985). Production and Utilization of Biogas in Rural Areas of Industrialized and Developing Countries, GTZ No.97, Eschborn, pp. 31-32.

ICC (2001). ICC Energy Commission energy related messages. http://www.iccwbo.org/, Accessed: August 28, 2002, 4p.
Kaparaju, P. and Rintala, J. (2005). Anaerobic co-digestion of potato tuber and its industrial by-products with pig manure. Resources, Conservation and Recycling, 43: $175-188$.

Kyei, M. (2005). Personal communication, Shebu Industries, Savelugu, Ghana.

Misi, S.N. and Forster, C.F. (2001). Batch codigestion of multi-component agro-wastes. Bioresource Technology, 80: 19-28.

Mshandete, A., Kivaisi, M., Rubindamayugi, M. and Mattiason, B. (2004). Anaerobic batch co-digestion of sisal pulp and fish wastes. Bioresource Technology, 95: 1924.

Person, S. and Bartlett, H.D. (1978). Converting manure into gas potential source of energy, The Pennsylvania State University. J. Science in Agric., 26(1): 15-23.

Sasse, L. (1988). Biogas Plants: Design and Details of Simple Biogas Plants. GATE/ GTZ Publication, Friedr. Vieweg \& Sohn, Braunschweig/Wiesbaden. pp. 10-12.

Steffen, R., Szolar, O. and Braun, R. (1999). Feedstocks for anaerobic digestion. ADNett, Technical Paper, 21p.

Veeken, A., Kalyuzhnyi, S., Scharff, H. and Hamelers, B. (2000). Effect of $\mathrm{pH}$ and VFA on Hydrolysis of Organic Solid Waste, Journal of Environmental Engineering, 12: 1076-1081.

Wildenauer, F. X. and Winter, J. (1985). Anaerobic digestion of high-strength acidic whey in a $\mathrm{pH}$-controlled upflow fixed-film loop reactor. Appl. Microbiol. Biotechnol., 22: 367-372.

Zauner, E. and Kuntzel, U. (1986). Methane production from ensiled plant material. Biomass, 10: 207-223. 